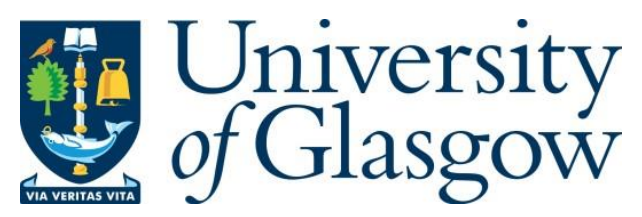

Brigden, N., and Mainwaring, $\dot{C}$. (2016) Matryoshka journeys: im/mobility during migration. Geopolitics, 21(2), pp. 407-434.

There may be differences between this version and the published version. You are advised to consult the publisher's version if you wish to cite from it.

http://eprints.gla.ac.uk/140024/

Deposited on: 24 April 2017

Enlighten - Research publications by members of the University of Glasgow http://eprints.gla.ac.uk 


\title{
Matryoshka Journeys: Im/mobility during Migration
}

\author{
Noelle Brigden \& Cंetta Mainwaring ${ }^{1}$
}

Published in Geopolitics 21, No. 2 (2016): 407-434.

\begin{abstract}
Acts of mobility require corresponding acts of immobility (or suspended mobility). Migrant journeys are not only about movement. Indeed, in the present policy context, this is ever more true. Whether a migrant is contained within a hidden compartment, detained by migration authorities, waiting for remittances to continue, or marooned within a drifting boat at sea, these moments of immobility have become an inherent part of migrant journeys especially as states have increased controls at and beyond their borders. Migrants themselves view this stopping, waiting and containment as part of the journey to be endured. Drawing on the authors' fieldwork in Central America and Southern Europe, this paper destabilizes the boundary between transit and settlement, speaking to a larger policy discourse that justifies detentions and deportations from the United States and countries on the periphery of Europe. We argue that migrants' nested experiences of these 'matryoshka journeys' reveal how increased migration controls encourage them not only to take greater risks during the journey, but also to forfeit their agency at opportune moments. In turn, states exploit images of such im/mobility during the journey in order to emphasize the irrational risks migrants take in order to traverse seas and deserts and to cloak their own border policies in a humanitarian discourse of rescue.
\end{abstract}

\footnotetext{
${ }^{1}$ Names are listed in alphabetical order.
} 


\section{Matryoshka Journeys: Im/mobility during Migration}

\section{Introduction}

Clandestine migration journeys are not only about movement. Whether a migrant is contained within a hidden compartment or smuggler's safe house, detained by migration authorities, waiting for remittances to continue, or marooned on a drifting boat at sea, moments of immobility are an inherent part of migrant mobility, especially as states have increased controls at and beyond their borders. ${ }^{1}$ In her study of a 'neoliberal securityscape' that detains and deports Salvadoran migrant youth on a massive scale, Elana Zilberg explains that, "globalization is better characterized by a dialectic of mobility and immobility." 2 Migrants themselves view stopping, waiting and containment as part of the journey to be endured. Indeed, the landscape of the routes people travel includes a variety of spaces where people loiter or find themselves detained.

This paper speaks to the literature that analyzes the spatial restructuring of borders at the periphery of the Global North. ${ }^{3}$ Drawing on fieldwork in the Americas and Southern Europe, our paper points to the way this restructuring ruptures and redirects unauthorized journeys, and, in doing so, destabilizes the boundaries between the conventional dichotomies of transit and settlement, and of trafficking and smuggling. ${ }^{4}$ In this way, we speak to a larger policy discourse that justifies detention and deportation from the United States, Mexico and countries on the periphery of Europe. In and around Europe and the Americas, intensified policing and criminal violence has transformed linear spatial movements into indefinite odysseys. ${ }^{5}$ Despite the clear similarities across regions, there has been little cross-Atlantic dialogue on how these effects are produced by policy and embodied in the lived experience of migrants.

By bringing together fieldwork from two continents, we demonstrate how common policing practices, and language of crisis and rescue, rupture clandestine migration journeys. The argument is made up of two parts, each of which focuses on manifestations of $\mathrm{im} /$ mobility along the migration journey. Firstly, we examine moments when migrants stop en route. Secondly, we examine the immobility that migrants endure when physically contained in boats, hidden compartments, trucks, and cargo holds in order to facilitate the onward movement of their journey. Migrants' nested experiences of these 'matryoshka 
journeys' reveal how increased migration controls encourage them not only to take greater risks during the journey, but also to forfeit their agency at opportune moments. ${ }^{6}$ In other words, migrants temporarily surrender control at points during the journey, accepting momentary disempowerment to achieve larger strategic goals. In the most extreme cases, this involves physical constraint or containment. Here, our work is informed by feminist scholarship that examines waiting, or immobility, and how it is actively produced, embodied, experienced, politicized and resisted across a range of migrant spaces'. ${ }^{7}$

States exploit images of such im/mobility during the journey in order to emphasize the irrational risks migrants take in order to traverse seas and deserts and to cloak their own border policies in a humanitarian discourse of rescue. However, this symbolic appropriation of images of immobilized migrants does not acknowledge how the policing context structures migrants' difficult choices or how migrants strategically engage immobility.

The article proceeds in four parts. First, we briefly introduce the methods we employ to arrive at these conclusions. Second, we compare the policy context on both sides of the Atlantic, demonstrating how in both regions, border controls have intensified and expanded geographically. Third, we explore the lived experience of migration to highlight the integral relationship between mobility and immobility in this policy context. We describe both the fragmented and nested nature of the transit experience. Fourth, and finally, we critique a discourse of rescue that justifies state responses to migrant $\mathrm{im} /$ mobility without acknowledging the agency of migrants or addressing the broader political reality of restrictive migration policies.

\section{Methods}

We employ an ethnographic approach to data collection and analysis. Separately, we conducted participant observation, semi-structured and unstructured interviews. Through iterative conversations and writing, we inductively recovered themes from migrant narratives of the journey. In this creative collaborative process, we arrived at an understanding of journeys as a nested series of journeys within journeys that could elucidate the relationship between state policies and migrants' lived experiences. Because such adventures are unpredictable and highly variable across time and space, it might be 
truthfully said that the only typical migrant journey is an a-typical journey. This complicates generalization both within and across cases. However, we included narratives that represent a larger mode of crossing, resonating broadly both within and across the two regions. Throughout the text, we juxtapose these narratives side-by-side, switching rapidly and frequently between the regional contexts, to give the reader a sense of the process we followed discovering the theme of nested experiences of immobility and mobility from our interviews.

Under the auspices of a larger project, Brigden conducted interviews between 2009 and 2012. In 2009-2010, she lived in migrant communities in El Salvador. In 2010-2011, she also volunteered at a Catholic migrant shelter in Oaxaca, Mexico. Thus, interview participants included Central American migrants (before, during and after their journey to the United States), deportees, family members, human rights activists, police and others living and working along migration routes from sending communities in rural El Salvador and through 12 transit communities across Mexico. The majority of migrants encountered in passage hailed from Guatemala, Honduras, and El Salvador in rough proportion to estimates of the overall flow of migrants who attempt to cross Mexico; a minority of migrants interviewed reported other nationalities, such as Nicaraguans, Mexicans, one Panamanian and even one Indian person. The sample included a small number of interviews in destination and transit communities within the United States in 2012.

Mainwaring conducted interviews with over 60 migrants in Malta and Cyprus between 2008 and 2011. She also carried out participant and non-participant observation within migrant communities on both islands. The migrants interviewed were from an array of African, Middle Eastern and Asian countries. Reflecting overall irregular migration flows to Malta during this time, the majority were Somali and Eritrean refugees who departed on boats from Libya and were rescued at sea by the Maltese Armed Forces. In Cyprus, some had arrived without authorization by crossing the Green Line that divides the island and others had overstayed their visas which initially permitted entry in order to study or work (most often as domestic workers). Compared to the majority of the Brigden's interviews, these took place further along the migration journey, when migrants had already arrived in Europe. Nevertheless, the interviews explored their entire journey from country of origin, as well as attempts at and desires for onward mobility into Europe. 
Bringing these two field sites into dialogue with each other is not wholly uncomplicated. While segments of the journey are sometimes made by boat, Central American migrants interviewed in Mexico tend to travel largely along land routes to a single nation-state destination, the U.S. The European Union, on the other hand, is a supranational union of 28 member states, any of which might be intended or de facto destinations for those arriving at its external borders. Furthermore, many migrants travel across maritime borders in the Mediterranean in addition to land routes in order to reach the EU. As has been forcefully revealed by the most recent high-profile refugee crisis, discrepancies between the regulatory frameworks of European states persist, despite attempts to create a common asylum and immigration system. ${ }^{8}$

The majority of migrants travelling to Europe without authorization apply for asylum once they arrive. In contrast, migrants clandestinely crossing the U.S.-Mexico border do not usually apply for asylum. However, the policy contexts may be growing more similar in this regard; between 2012-2014, the US Border Patrol documented a tremendous spike in unaccompanied Central American children and asylum claims based on gang persecution. Between fiscal year (FY) 2013 and 2014, apprehensions of unaccompanied minors grew $77 \%$, rising from 38,759 to 68,541 children encountered at the southwest border. ${ }^{9}$ Based on a survey of 404 children in custody, a 2014 UNHCR report found that a majority of Central American child migrants suffered forcible displacement and needed international protection. ${ }^{10}$ In FY 2013, 15\% of migrants under expedited removal (the streamlined deportation process that occurs at the border) claimed credible fear of return, thereby becoming asylum seekers, up from the $4-6 \%$ of apprehended migrants in the 20002009 FY periods. ${ }^{11}$ Not coincidentally, this 'humanitarian crisis' at the U.S. border resolved only after Mexico intensified efforts to stem the tide of migrants before they reach U.S. soil. Apprehensions of unaccompanied children at the U.S. southwest border declined $46 \%$ between FY 2014 and FY 2015.12 As we will discuss, the subsequent decrease in entries of potential asylum seekers across the U.S.-Mexico border is a testament to the 'success' of this transnationalized migration policing policy, not the changing character of the migration flow. Despite their differences, destination countries on both sides of the Atlantic seek to shift asylum responsibility. 
This convergence of purpose points to the fact that, despite the potential complications of such comparisons, cross-regional research on clandestine routes is imperative to understanding global patterns of border policy and migrant (im)mobility. As we demonstrate, migrants on both sides of the Atlantic face similar challenges and opportunities during their journeys. Comparing their experiences draws attention to: the similar state bordering processes occurring in Europe and the Americas that cause these journeys to become more fragmented; the ways in which migrants use im/mobility in order to overcome migration controls; and the ways in which their strategies are co-opted by states in order to justify further controls. Thus, in the next section of the paper, we further outline the similarities between the two policy contexts, thereby justifying the comparison of Mediterranean and North American journeys.

\section{Policing Peripheries, Constructing Crises}

On both sides of the Atlantic, restrictive immigration policies, the geographical extension of policing away from borders, increased surveillance across and within nationstates, international security cooperation, deportations, lengthy detentions for illegal entry, and the denial of asylum claims conspire to prolong transit for migrants. Taken together, this restructuring of migration regimes has resulted in a "thickening" and delocalization of borders. ${ }^{13}$ As Alison Mountz argues, the mobilities paradigm has overlooked the 'mobility' of states in their engagement with human migration: to control the movement of people, states also move by shifting their legal and territorial boundaries, policing patterns and entry points to intercept migrants. ${ }^{14}$ We contribute to this literature by tracing how European and U.S. migration controls move beyond (and within) the border and intersect with the im/mobility of migrants en route. While these policies continue a longer trend of policing and border militarization over the last century, ${ }^{15}$ such efforts accelerated dramatically in the aftermath of the 2001 attacks in New York City. ${ }^{16}$ The discourse of migrants as a national security risk justified putting migrants' human security at risk during their journeys. ${ }^{17}$

Immigration Control in North America 
Since that time, the United States has internalized and externalized its borders. In addition to enhancing the fortification and technological sophistication of the U.S.-Mexico divide and other ports of entry, the U.S. government has increasingly turned to internal migration policing for territorial control. These internal controls include highway checkpoints, surveillance of public transit and other public spaces within an extended border zone inside the United States, criminal incarceration for immigration offenses, and legislation to facilitate the removal of legal migrants for minor criminal infractions, as well as partnerships between local law enforcement and federal migration authorities. ${ }^{18}$ The result has been a dramatic increase in immigrant detention and deportation. ${ }^{19}$ The post9/11 reorganization of the Immigration and Naturalization Service (INS) as the U.S. Immigration and Customs Enforcement (ICE) under the Department of Homeland Security (DHS) also blurred the boundary between domestic and foreign security.

Like its European counterparts, the United States has also quietly turned its attention to its periphery, seeking to stem clandestine flows of people and goods before they arrive at the country's doorstep. In the context of the 1980s Central American refugee crisis, with hundreds of thousands of Salvadorans and Guatemalans fleeing civil conflict, the United States began to pressure Mexico to stem the tide of transit migration. ${ }^{20}$ While Mexico does not restrict the travel of its own nationals to the United States, ${ }^{21}$ it has become a willing partner in the policing of clandestine transit flows across its territory. Mexico has harmonized its own visa requirements with its northern neighbor ${ }^{22}$ and also instituted several programs to intercept, detain and deport unauthorized Central American migrants. From 2001-2003, it adopted 'Plan Sur', which established internal control belts across transport routes frequented by migrants. ${ }^{23}$ Plan Sur also sponsored inter-agency cooperation, blurred the boundary between the drug interdiction mission and immigrant apprehensions, and centralized deportation procedures. ${ }^{24}$ While the size of the program remains unclear, after 2001, the United States funded a portion of the expenses for deportations of Salvadorans and Hondurans from Mexico. ${ }^{25}$

At the official conclusion of the first Plan Sur, the Mexican government continued similar policies. ${ }^{26}$ Between 2001 and 2007, the number of migration detention facilities had increased from 25 to 48 and dispersed geographically across the Mexican countryside. ${ }^{27}$ Migration raids on freight trains also became more commonplace and covered more 
territory. ${ }^{28}$ In 2005, mirroring post-9/11 institutional reorganizations in the United States, the Mexican immigration agency (INM) came under the control of the Mexican National Security Council. Some observers complained that these changes converted Mexico into a 'vertical border' for the United States. ${ }^{29}$ In fact, these earlier control efforts have been overshadowed by the more recent, unprecedented bilateral cooperation between the United States and Mexico under the ongoing Mérida initiative, which sponsors interdiction efforts, surveillance and police capacity to stem clandestine flows of goods and people. Since 2011, the U.S. investment in Mexican border control has been massive enough that Assistant Secretary of Homeland Security for International Affairs Alan Bersin declared, "the Guatemalan border with Chiapas is now our southern border."30

In 2014, following in the wake of a sudden influx of unaccompanied Central American minors and asylum seekers, referred to by President Obama as a 'humanitarian crisis', Mexico launched a reinvigorated Plan Sur. This new Plan Sur primarily targets the southern train routes that the poorest Central Americans traverse to arrive in the US. The Plan lists the protection of migrants as one of its primary objectives, and explicitly seeks to prevent migrants from "putting themselves at risk" by boarding the freight trains. ${ }^{31}$ Despite this emphasis on "protection", deportations to El Salvador, Honduras and Guatemala from Mexico have risen dramatically, surpassing the number of deportations of Central Americans from the United States. ${ }^{32}$ Indeed, the recent decline in apprehensions of Central Americans at the U.S. border is largely (though not exclusively) a consequence of this increased Mexican enforcement effort. ${ }^{33}$ Mexico's role as a migration buffer has become ever more important to the control of the U.S. border.

Under the programs sponsored by these initiatives, control of drug and human smuggling routes are conflated as one national security issue. In response to criticism of this trend by human rights advocates, the 2011 Mexican constitutional reforms declared that unauthorized entry cannot be criminalized and recognized the universal human rights of irregular migrants. Unfortunately, these reforms also explicitly link migration to national security. ${ }^{34}$ While acknowledging his duty to protect the basic rights of migrants, the recently appointed INM Commissioner, Ardelio Vargas Fosado, reaffirmed his commitment to a national security approach to policing migration. ${ }^{35}$ The 2013-2018 strategic plan released by the Mexican Secretary of National Defense (SEDENA) re-commits to the 
national security priority of border enforcement. The plan urges further intra-agency collaboration, international cooperation, and the dedication of approximately 30,000 military personnel for this endeavor. ${ }^{36}$ Thus, Mexican migration controls have been justified by both national security and humanitarian crisis.

\section{Immigration Control at the Periphery of the EU}

Across the Atlantic, member states have emphasized the need to control migration at the European Union's external borders, especially following the relaxation of internal migration controls under the Schengen Agreement (1985). This process of moving border controls and asylum responsibility towards the edges of Europe has subsequently included the Dublin Convention (1997) and the related Eurodac database (2003), the establishment of Frontex (2005), the EU's external border agency, and most recently the European Border Surveillance System (2013), a platform for information sharing between member states in order to detect unauthorized cross-border migration. ${ }^{37}$

Alongside the outward movement of migration controls within the EU, member states have pursued the externalization of controls at the regional and national levels. The EU and its member states have encouraged countries on its periphery to develop traditional instruments of migration control (i.e. border patrols and other measures to combat 'illegal' immigration, smuggling, and trafficking) and to improve their asylum systems. The bloc has frequently linked development aid and agreements on trade or technical cooperation to the implementation of such migration controls. ${ }^{38}$ Countries along the eastern and southern rim of the EU are thus being co-opted to varying degrees into becoming what is effectively a migration buffer for Europe. ${ }^{39}$ For those migrants who nevertheless arrive in Europe, there has been a second line of defense involving provisions for the return of migrants and asylum seekers to third countries by way of readmission agreements and the introduction of the principle of 'safe third countries' 40

Despite such measures, there has been limited success at externalizing migration control at the multilateral level. Member states along the EU's periphery have thus turned to negotiating formal and informal bilateral cooperation agreements with neighboring states in order to facilitate forced returns. ${ }^{41}$ Spain was one of the first southern European states to sign a readmission agreement in order to externalize migration controls. In 1991, 
it signed an agreement with Morocco that allowed for the return of Moroccan and thirdcountry nationals. ${ }^{42}$ This was followed by a rash of agreements, made under Spain's Action Plan for Sub-Sahara Africa, with Guinea Conakry (2007), Cape Verde (2008), the Gambia (2008), Guinea Bissau (2008), Niger (2008), Senegal (2008), Mali (2009), and the Cameroon (2011). ${ }^{43}$

Similarly, in the face of increasing flows of irregular immigration across the Central Mediterranean around 2002, Italy signed a variety of agreements that included readmission clauses with Tunisia (2003), Egypt (2007), and Algeria (2009). In 2008, Italy also negotiated a Treaty on Friendship with Libya that informally acted as a readmission agreement. ${ }^{44}$ The eruption of the Libyan Revolution in 2011 halted the so-called push back policy of returning boats from international waters in the Mediterranean to Libya, a practice that the European Court of Human Rights (2012) subsequently condemned. Nevertheless, Italy quickly signed a new memorandum of understanding with the Libyan Transitional National Council in 2011, which confirmed both parties commitment to the 'management of migration, primarily through ... cooperation in combating terrorism, organized crime, trafficking in narcotic drugs and psychotropic substances and illegal immigration'. ${ }^{4}$

The interpretation of irregular immigration as a security or humanitarian crisis provides the context for the justification of these externalization policies. Crisis discourse underlines the need to control unbridled migration flows and restore order, while also rendering controls as humanitarian efforts to reduce deaths at sea. For example, Frontex's 2006 Annual Report notes that its mission in the Canary Islands stopped 'illegal immigrants... from setting off for a dangerous journey that might have cost their lives'.46 Alongside efforts to substantiate and reinforce the crisis though external migration policies, crisis discourse has been used to justify internal practices of control that project the sovereign power of the state to control its borders. ${ }^{47}$ For example, Greece, Italy and Malta all enforce lengthy immigration detention periods of between 12 and 18 months. ${ }^{48}$ In 2008, Italy amended its law to make irregular status an aggravating circumstance in criminal cases. The law also criminalized the act of renting accommodation to irregular migrants, which can now carry a prison sentence of up to three years. Greece constructed a 12.5kilometer, barbed-wire fence in Evros, along a section of its land border with Turkey. The 
country's Minister of Public Order and Citizen Protection, Nickos Dendias, has noted efforts to deter irregular migrants by turning the country into an 'unfriendly destination'. ${ }^{49}$

\section{The Lived Experience of Migration: Fragmented Journeys and Matryoshka Journeys}

These policies generate a particular lived experience of geographic mobility, one that is inextricably tied to experiences of immobility. The policing and deportation justified by crisis produce further mobility, as deportees attempt return again and again. ${ }^{50}$ In this section, we examine two different forms of im/mobility that occur in the context of the journey: 'fragmented journeys' and 'matryoshka journeys'.

First, the contemporary migration policing regime increasingly requires migrants to adjust to unforeseen events with flexibility en route. Michael Collyer has examined 'fragmented journeys' across North Africa. ${ }^{51}$ We show that this fragmentation is global. Migration journeys are rarely a linear passage, travelled form point of origin directly to destination. Rather, migrants make these journeys in broken, unplanned stages; a failed stage may give rise to another unexpected leg of the journey. We find that in the Americas too, journeys take unexpected directions, migrants continually change their destination, and as the difficulty of arrival and settlement increases, people wander in search of opportunity. The boundary between transit and settlement becomes blurred, as migrants move indefinitely and sometimes spend very long periods in countries of transit, rather than the destinations they initially envisioned. Indeed, this form of immobility is part physical and part temporal. Many journeys are characterized by long periods of 'sticky' or even 'suspended' time spent waiting, stopping, and being stranded or contained. This sticky or suspended time is punctuated by moments of 'frenzied' time experienced with urgency and sudden movement. ${ }^{52}$

The second, related dimension of immobility is a layered relationship between empowerment and disempowerment, which can be explained with the metaphor of the matryoshka journey. The matryoshka is a nested series of dolls, with one face concealed within another. Likewise, migration journeys become a nested series of adventures and concealment strategies, as migrants attempt to evade capture by the state or escape violent criminal predators. The fragmented nature of journeys encourages this nested experience. However, these two concepts are analytically separate: one might experience the journey 
as matryoshka without experiencing fragmentation. Migrants may need to undertake journeys within journeys, not only by changing direction, taking meandering routes away from their destination or waiting for opportune travel conditions, but also by strategically forfeiting or reclaiming control over their own body in transit. Thus, in these moments, migrants may be rendered physically immobile in the most extreme forms, for instance, while in secret compartments, boats, trucks or smuggler's safe houses.

Migrants often accept this extreme form of immobility and the bodily risks involved in this loss of control as necessary in order to evade other dangers, usually those associated with their visibility to the state. In so doing, they barter moments of immobility for mobility, and moments of disempowerment for a larger purpose. On the other hand, migrants sometimes find ingenious ways to negotiate limited control over their fate when in official custody or in the hands of smugglers. Migrants are rarely passive victims in such circumstances. By peeling back the layers of these journeys, we find that this form of immobility is a complex negotiation of risk, agency and visibility.

Migrants understand periods of waiting, stopping and containment as inherent to the migration experience. The patience to cope with indefinite periods of immobility becomes a survival resource, as the experience of immobility folds into the larger purpose of mobility. Moments of mobility occur within their forced immobility, and immobility occurs within the larger context of migration and life-long journey to unknown destination. As explained by Melvin, ${ }^{53}$ a Salvadoran man who stayed several months at a midpoint along the route through Mexico, "I am doing it slowly, working. Where there's work, I will stay for a while. It's not good for the body or soul to only be traveling, doing nothing, not working. The body needs to be busy.... The traveling life is hard. Many people fall into drink and vices. I am going slowly" (Interview, Mexico, 11/17/10). For Melvin, the conceptual bifurcation of transit and settlement is unhealthy, especially since his journey to the United States is an indefinite one. He had already failed to arrive once, captured by U.S. border patrol at the crossing and deported back to El Salvador. Acknowledging that the journey might not end, Melvin had to incorporate the habits of a settled life into his travel to stay sane. He could not pretend the journey was a momentary transition. The metaphysical journey of life and the physical journey across terrain had become inexorably intertwined, 
complicated by the conditions of the migration route. His journey is both fragmented and nested within multiple personal narratives.

The fragmented and nested nature of these journeys reveals yet another layer in the experience of the migration journey. Migrants exploit narrow margins in situations where they may, at first glance, seem powerless. In Collyer's analysis of fragmented journeys, being 'stranded' increases the vulnerability of migrants. Indeed, fragmented journeys often involve more risk to migrants: for example, a recent European study on smuggling networks from Ethiopia to Libya reveals that migrants face greatest danger, uncertainty and violence when they must negotiate their transfer between different smuggling networks. ${ }^{54}$ Nevertheless, our analysis of matryoshka journeys adds to this literature by examining, not only fragmentation, but also the purposeful surrender of agency as a survival tactic within larger geographical and life trajectories. When viewed within this larger complex of goals, moments of immobility are not just ruptures, but also rungs on a ladder to further movement. Furthermore, during these moments of rupture - which are experienced differently as refusals, restarts, indefinite suspensions, voluntary interruptions or forced terminations - migrants devise nested tactics and strategies to achieve both immediate and long-term goals. When we understand journeys as both fragmented and matryoshka-like, a nuanced view of migrant agency emerges.

\section{Unpredictable Journeys, Predictable Immobility}

The outcome of each journey is uncertain. While migrants understand that the journey is risky and often have an accurate idea of the life and death stakes they will encounter en route, they cannot accurately judge the probability of arrival or death.55 Nonetheless, even during a 'successful' journey, migrants expect moments of immobility, and journeys fragmented by hardship and loss of control.

Some of this unpredictability results from the fact that travel conditions and vehicles vary dramatically within journeys, as well as across them. In a single journey, migrants en route to the U.S. and Europe may travel by boat, freight train, bus, foot, bicycle, private car, in secret compartments in cargo trucks, and even in ambulances. Migrants and their smugglers may unexpectedly change their manner of travel in response to changes in policing or criminal threats. Migrants who travel with large scale smuggling operations 
often endure extremely cramped conditions in 'safe houses', as they wait for the next segment of the journey. These stays may last from a few hours to months, often in private homes. Changes in policing, criminal threats, fluctuations in the organization of smuggling networks or even weather may cause delays. Migrants may be held captive against their will, fed poorly, physically abused, or subject to unwanted contract renegotiations with their smugglers. Alternatively, some migrants report good treatment and comfortable stays in hotels.

Benjamin, a Congolese journalist and activist, fled his home in Goma fearing retribution for his work (Interview, Cyprus, 4/8/2009). His journey occurred in multiple, fragmented and unplanned stages prompted by barriers and opportunities that arose, as well as information he obtained en route. The journey took him through five countries and would eventually end, at least temporarily, in Cyprus. He first travelled to Uganda, crossing the border during market day, when border controls are relaxed in order to facilitate economic flows. Using a bicycle, he disguised himself as a local villager with wares to sell. With the help of family members in Uganda, he travelled by plane to Kenya and then to Syria. Because he did not have a visa, he was detained upon arrival in Damascus, but released when he convinced officials he was in Syria to establish business contacts, producing $\$ 2,000$ as evidence. The Syrian officials nevertheless confiscated his passport and demanded he come back within a week with proof of his return ticket. Upon release, Benjamin contacted smugglers who organized a bus northwards out of Damascus for a group of 40 migrants made up of men, women and children from different countries. Benjamin spoke to fellow passengers from Algeria, Sierra Leone, and Ethiopia.

Once they neared the Turkish border, the group started on foot. Benjamin explained, "[It took] two nights walking. We have to walk only during the night. During the day, you are in the bushes sleeping." Once they had crossed the border into Turkey, other smugglers met them and packed them into cars. The migrants endured these cramped conditions as they progressed towards Adana, the nearest big city. A separate car travelled ahead warning of any military checkpoints. In these instances, the cars would stop and wait until the checkpoint was cleared. Once in Adana, Benjamin and his fellow passengers bought bus tickets to Istanbul. 
Benjamin wanted to apply for asylum in Istanbul but was informed by other migrants that he needed to go to Ankara to do so. Meanwhile, he met Congolese migrants who had been forcibly returned from Greece. He also heard that it was relatively easy to travel to Cyprus from Turkey. Thus, after two weeks in Istanbul, he paid a man from Burkina Faso $\$ 150$ in order to use his passport and Turkish visa. ${ }^{56}$ Although he did not resemble the man particularly well, Benjamin explained, "Because we are Africans and the police, immigration, they see someone from Africa, so they just [think] it's the same person. Although the faces are not the same!"

Once Benjamin arrived in northern Cyprus, he was put in a safe house in Famagusta with other migrants. Here, the smugglers demanded more money in order to help them cross to the southern side of the island and into the EU member state. While they waited in the safe house, two men arrived saying they were the police and asking for papers. They left only after stealing everybody's money, including the last $\$ 600$ Benjamin carried.

In the Americas, smugglers also use an extensive network of safe houses. Despite bursts of sudden and fast movement across long stretches of terrain, it took Joel, a shopkeeper from rural El Salvador, seventy days to arrive in the United States. The smugglers kept taking him to houses in Mexico where he would spend weeks at a time. In one house, they kept one hundred people, including men, women and a few children, with only one bathroom. The food was horrible, but the people could not complain. Any noise would invite the attention of the neighbors, who would call the police. And no one could leave. The smugglers kept the door locked with everyone inside. I paused Joel to ask him, "What if there's a fire?" "Then everyone burns." Joel continued to explain the conditions inside these safe houses. Women kept the houses, brought them food and sometimes drove them for segments of the journey. These women would drive the migrants around and around in circles to disorient them before arriving or after leaving each house. That way, the migrants would not be able to tell authorities where they had been held. He never knew where he was. There were people from many different countries, and the smugglers would continually add people to the group. In another house, where he was kept in deplorable conditions for many weeks, he was told that the delay was due increased military presence in the area. One woman lost her patience and escaped. The smugglers opened the door for something, and she ran out. Joel thought she got away. 
This system of safe houses continued into the United States, and he waited in one in Los Angeles, locked inside, while his girlfriend's sister gathered the money to pay the smuggler for his delivery. She was late, and they had to pay extra charges for food and accommodation. The longer it takes to come up with the money, the bigger the bill. Sometimes they charge as much as $\$ 100$ per day. I paused Joel again, "What happens if your family doesn't pay?" "Then you stay." I asked for clarification, "Forever?" He shrugged, "maybe... Yes. It's possible, but everyone pays. The family always pays."

These narratives reveal how migrant journeys toward Europe and the United States are rarely linear, premeditated passages. Rather, they are circuitous, fragmented voyages involving periods of immobility of varying lengths in countries of 'transit'. Migrants reimagine their routes and destinations as new barriers, dangers or opportunities arise. Unplanned periods of immobility and reimagining are perhaps the only predictable experiences of the journey.

\section{Perilous yet Necessary}

However, fragmented trajectories are only one dimension of the narrative; people experience clandestine migration as nested moments of movement and stasis, in other words, as Matryroshka journeys. They understand that empowerment may require their acceptance of temporary immobility. As they journey northwards, migrants recall these moments of physical immobility as perilous yet necessary, and sometimes identify even the most severe physical constraints as a strategic calculation in pursuit of mobility. Mario described being hidden in the secret belly of a cargo truck, during a short segment of his journey from El Salvador to the United States in 2000 (Interview, El Salvador, 3/1/10). He demonstrated his position within the small hidden compartment, with his head turned slightly and his body curled into a ball. Mario and his travel companions were trapped inside until Puebla, a city in the central zone of Mexico. At a checkpoint, he heard migration agents asking "you carrying pollos [directly translated chickens, derogatory slang for smuggled people] in there?" and banging on the walls of the vehicle. The agents walked loudly over the top, while everyone inside sat silently. Mario could not shift his weight without hitting the body of another person. People urinated on themselves and each other, but Mario says, "The guides were smart"; they gave him a pill to prevent him from 
defecating. The truck passed the checkpoint. When the smugglers unloaded their cargo, all the people were numb. None of them could move. The smugglers dragged them out, pulling on their ankles or legs, and dumped them onto the ground like bags of potatoes. People would fall and lie there immobile for a while, as the blood returned to their limbs. It would take thirty minutes before Mario could move.

Mario contrasted this terrifying experience of extreme immobility, including the paralysis and betrayal of his own body, to his time crossing the notoriously dangerous Arizona desert: "The desert felt fine. I am from the campo [rural countryside]." So, Mario was accustomed to heat and working outside. Despite Mario's confidence, the desert is a site of death: the U.S. Border Patrol reported 6,029 deaths on the U.S.-Mexico border between 1998 and 2013. ${ }^{57}$ The total number of deaths is likely to be much higher than those bodies found and reported by the U.S. Border Patrol. Where many migrants find hardship, exposure to the elements and even death in the formidable natural environment of the U.S.-Mexican borderlands, Mario felt at home, moving forward through the open expanse of wilderness. Flexing his muscles and changing his posture to show me during our conversation, he boasted that he was built for it. In some instances, the containment and forced immobility of migration is more terrifying than any risk faced by migrants as they progress across the landscape.

In other instances, oppressive landscapes exacerbate physical immobility. At sea, geographic markers recede into the unfamiliar and uniform watery panorama. In this situation, migrants are trapped, immobilized within boats. Abu, a medical student from Somalia, described his experience crossing the Mediterranean: "[At sea,] there is something: fear. When you see the sea from all sides, and you see the sky above - blue and blue - there's nothing. It's just silent. You risk yourself, your life, your family" (Interview, Malta, 5/7/2011). Many migrants who cross the Mediterranean have already suffered cramped, difficult conditions in order to cross the Sahara Desert. Their journey from Africa to Europe is made up of multiple, nested journeys across different landscapes. For instance, Aman, a young Eritrean, described the fear that took hold while crossing the Desert from Sudan to Libya (Interview, Malta, 3/4/2009). Twenty-five migrants were packed into a jeep in Khartoum for a journey that would take 15 days. "In the desert, 15 days [feels like] 15 years", he recalled. The unfamiliar environment and geography contributes to the fear 
migrants feel as they are confined in jeeps and land cruisers at the mercy of their smugglers. During these desert journeys, they withstand extreme heat and cold often with very little food and water. Nevertheless, at sea and on land, migrants accept immobility and confinement in a boat or in a Jeep in their attempts to access mobility and further their journeys. These migrants view such decisions not as acts of desperation but as strategic maneuvers in the face of limited choices.

For some, the desert crossing is fatal, and their bodies act as a reminder to others. Death in the desert without proper burial is, perhaps, the ultimate form of immobility: stranded physically or spiritually along a clandestine route as an anonymous body. This immobility and anonymity touches even the family members of missing migrants, rendering them incapable of 'moving on' psychologically without knowledge of the fate of their loved ones. Kele, a young Nigerian, described his experience in the Sahara:

When you're in the desert, you see people, the dead ones; you see that skeleton of people, some female, some male. Even the ones sitting with you, some end up there because no food, no water, you don't know where you go, you don't know where you're coming from and the heavy sun. So if you're not strong, you lose your life (Interview, Malta, 9/4/2009).

Fear of death permeates moments of physical immobility, withstood in order to facilitate mobility. Joel, the shopkeeper from rural El Salvador, was one of one hundred people loaded into a tanker truck that typically carried liquids (Interviews, El Salvador $3 / 29 / 10 \& 4 / 11 / 10$ ). It was hot and there was no air. The smugglers closed the hatch to go through migration inspection points in the interior of Mexico and people began to asphyxiate. The Mexican authorities rescued them at a roadblock, but Joel was convinced that had they continued undetected, people would have died. His fears may have been well grounded. For example, in what journalist Jorge Ramos has called "the worst immigrant tragedy in American History", 19 people suffocated inside a locked trailer in Texas in 2003.58 Across the Atlantic, the corpses of 71 refugees were found in the back of a meat truck in Austria in late August 2015 after they died of asphyxiation. ${ }^{59}$ Stories about fatalities circulate widely in Central America, and migrants generally understand this danger when they embark on their journeys. After their rescue, the migrants in Joel's group 
were deported, but smugglers generally guarantee three attempts for the initial payment, and knowing the dangers intimately, Joel tried again with the same guide.

The next time, the smugglers hid Joel in the floorboards of cars, in a hidden compartment in a military vehicle, in plain view on an airplane, in small groups in taxis and even inside an ambulance traveling with its lights on. In Mexicali, a Mexican city near the U.S. border, he entered another crowded hidden compartment, similar to the one he experienced on his first attempt to cross. When he got out, Joel couldn't move. His body was asleep. He had been one of the first loaded in, and he had a fat woman on top of him the whole time. The smugglers had to drag him out by the arms and legs, and tossed him under a tree. He was completely numb. Helicopters circled overhead, near the U.S.-Mexico border. The smuggler warned him not to move, but Joel was stricken with fear that the police would come, everyone would run, and he would just be laying there paralyzed. He thought it must have taken over an hour before he could move again. Although fear permeates these moments where migrants surrender control over their journeys and their bodies, they accept such perilous risks as necessary in order to attain the goal of mobility.

\section{Reclaiming Control}

While Joel's story illustrates how a loss of control and containment may be perceived as an inevitable part of the journey, migrants may also be defiant and regain control in these moments in surprising ways. While they may surrender control to a smuggler and expect that smuggler to dominate decision making, they nevertheless continue to develop tactics for dealing with smugglers, travel companions, new situations and dangers en route. Indeed, migrants continue to negotiate with each other, their smugglers and state officials during their journeys. They may call for help from within the confines of a hidden compartment or even, on occasion, refuse to enter. Such resistance is not always successful, but nevertheless, migrants rarely passively accept complete control by smugglers, police, kidnappers or even the physical confines of their containment.

Kevin's story, one of many tales of defiance or manipulation of smugglers, illustrates this form of resistance (Interview, El Salvador 2/26/10). His mother had left for the United States when he was only three, and his grandparents had raised him. He loved them as though they were his parents, but he longed to be reunited with his mother. In 2005, two 
years after graduating high school, Kevin convinced his mother to pay the $\$ 6,000$ for a smuggler. She had hesitated, knowing all too well the suffering that would await him during the journey. She had been jailed in Mexico, and her friend had died in the desert. His family thought his crossing would be too dangerous, but Kevin insisted. The morning of the journey arrived, and to his surprise, several friends convened upon the smuggler's designated meeting place: "It was like leaving high school with all my friends in the street." None of his acquaintances had discussed their plans to leave, and it came as a pleasant surprise to know his travel companions intimately.

In fact, this camaraderie changed the course of their journey and may have saved their lives. At a midpoint in the journey across Mexico, they had been instructed to enter a hidden compartment in a transport vehicle. The ventilation in the compartment did not look sufficient to support the entire group, and Kevin felt immediately wary of the small space. When one migrant refused to enter, they all did. Normally, migrants feel both peer pressure and fear of abandonment when confronted with this choice. If only one migrant refuses to enter, he or she may be left behind without any resources, in great danger of police apprehension and/or criminal predation. In this moment, however, the smuggler could not leave an entire shipment of people behind, and he found a walking route to the destination instead. The migrants had successfully demanded their mobility without containment, rejecting the dramatic physical immobilization that accompanies transport within hidden compartments. This agency occurred within a larger context of disempowerment vis-à-vis the smuggler, who still exercised control of the group.

These expressions of migrant agency are echoed across the Atlantic. In the Mediterranean Sea, migrants immobilized in often-unseaworthy boats negotiate with coast guard officials of southern European countries. For instance, many migrants report that, when the Armed Forces of Malta (AFM) intercept their boats at sea, officials exert pressure on them to continue to Italy, either through delays in rescue, threats of the long detention period and other difficulties they will face in Malta, or offers of food and petrol to incentivise onward mobility. Despite the clear power discrepancies, migrants leverage their knowledge of international laws that require rescue at sea, of national flags that may identify a rescue vessel's flag state, and of languages that identify officials' nationalities. 
Ibraahin, a young Somali refugee, described the negotiation that took place when an AFM vessel intercepted their boat, which had been adrift in the Mediterranean for days and was taking on water (Interview, Malta, 13/4/2011). Ibraahin implored the officials to rescue them. An official responded that they would fix their engine and provide some petrol so they could proceed to Italy. Ibraahin protested that he and his fellow passengers did not know where Italy was, but the official reassured him that they would help them find their way. Unconvinced, Ibraahin said they could help them by rescuing them. Instead, the Maltese officials informed them that they would give them two hours to decide if they wanted to go to Italy or not. Meanwhile, a fellow passenger told Ibraahin that he recognized the Maltese flag flying above the AFM vessel. When the AFM returned, Ibraahin declared that they were headed to Malta, to which the official responded sarcastically, "Are you going to swim?" However, the officials eventually capitulated and rescued the migrants from their sinking boat. Although not all instances of negotiations are successful, as the number of deaths on the borders of Europe and the United States attest to, they do indicate some room for maneuver, some ability to control one's situation, even when immobilized. The experience of concealment and confinement reveals the matryoshka layers of human agency.

\section{Never-ending Journeys}

Journeys and forms of im/mobility continue even once migrants have arrived in Europe or the United States. The expansion of immigration detention and deportation regimes on both continents during the last decade contributes to continued im/mobility. More generally, an irregular status confines migrants to particular neighborhoods, jobs, and lifestyles. ${ }^{60}$

Patrick (Interview, Malta, 1/9/2009), a Sudanese asylum seeker, described how he felt after surviving the Mediterranean crossing only to be immediately detained in Malta: 61 "[Detention] made me crazy. It [is] like a jail. I applied for asylum but heard nothing for three or four months. I kept having nightmares and knew that I couldn't stay in detention". Indeed, migrant detainees often describe their time in detention as a waste of time, during which their sense of time decelerates as they wait for release with very little to do. Imminent and uncertain deportation contributes to this sense of 'sticky time' and unease. 
This 'sticky time' may be ruptured without warning by 'frenzied time' when a series of events happens quickly and accelerates one's temporal sense. Deportations, dawn raids, and 'fast track asylum processes' indicate this interplay between frenzied and sticky time (Interviews, Malta and Cyprus, 2008-2010). ${ }^{62}$ In the United States, the tightening nexus of criminal and immigration law has fast tracked removals of migrants suspected of criminal activity. As explained by Stumpf, "Crimmigration law wastes one of the law's most valuable tools: time. It eschews the temporal gauges that criminal law and immigration law rely on to evaluate who should be included or expelled from society." 63

Collaboration between police and immigrant enforcement has been widespread in the United States. As a result, migrants experience socio-economic and geographic immobility after their arrival. They cannot move freely within U.S. communities or across the country, for fear of apprehension. Without papers, they feel socially isolated and lack economic opportunity. This immobility within their destination may be interrupted by the forced mobility of deportation and return. Ultimately, migrants may feel trapped in their country of origin, with a sense of immobility thrown into particularly sharp relief by a failed migration attempt.

For example, when Walter graduated high school, his father sold his car and some land to pay a smuggler $\$ 5,000$ for the journey from El Salvador to the United States (Interview, El Salvador, 4/17/10). ${ }^{64}$ However, life in the United States did not resemble the experience he had imagined. As a stranger to the place, without a network of friends or knowledge of the locale, there was nothing to do but work. Nevertheless, Walter had trouble keeping jobs. With idle hours, Walter ultimately fell into trouble with the law. He was arrested and sent to prison in Pennsylvania and then to an immigrant detention facility in Texas, where they treated him "like an animal." A diabetic friend died in immigration custody while they awaited deportation, and Walter blames the migration authorities for not providing access to medical care despite the migrant's continued requests. He claimed that no one had access to a doctor or a lawyer. Walter also said that they threatened him with 'the hole', and deprivation of food, water and air, if he refused to sign his deportation papers. He signed.

Walter was so angry in detention that he had sworn he would kill the first American he met in his own country: "Americans come to my country as they please and enjoy the 
beaches. And they treat me like this." At this point in the interview, Walter looked away from me (an American) for a moment, and then put himself in the physical position that the authorities kept him for transport on the airplane, cuffed and curled under chains connecting his hands, stomach and feet: "like I had killed twenty people...like an animal." The marshals on the airplane were even worse. They threw his food at him, and chained in this manner, he could not eat his baloney sandwich. The migrants struggled to reach their food and drink their water through a straw. The marshals called him names: "They pry open your mouth and poke their fingers in your ears to make sure you're not carrying anything." Walter hypothesized that it was a strategy to traumatize people so they don't come back. "I really was going to kill an American [after that experience]...." Walter had felt stuck in the United States, unable to make friends or find fulfilling employment as an immigrant, then caged like an animal in prison and during the deportation process, and now he felt trapped again in El Salvador after a humiliating return.

For others, the matryoskha journey continues in the form of further (forced) mobility. Patrick, the young Sudanese man, escaped from the oppressive Maltese detention center and soon found a smuggler to take him to Italy (Interview, Malta, 1/9/2009). In Italy, he was apprehended and returned to Malta, where he was once again put in detention. After a month, he received temporary humanitarian status and was released. He worked in order to make money to buy a ticket to Switzerland. From Switzerland, he journeyed into France, and in Calais squeezed into a lorry with other migrants to cross the Channel. He recalls the fear that permeated the long five hours he spent hidden in the cramped space. Upon arrival in England, he was apprehended again and eventually returned to Malta under the Dublin Regulation when his fingerprints were found in the Eurodac database. Despite these many attempts, he was still determined, "I really wanted to do something for myself and my future but there's no work here, no school, no college. If I stay in this country, I'm going to lose myself." As they confront the possibility (and reality) of multiple deportations, migrants describe a perpetual sense of immobility and an ongoing struggle for mobility.

\section{False Rescues}


The global, regional, and national structures through which migrants travel limit their choices, but do not eliminate them; migrants may understand the dangers involved and nevertheless choose to endure dangerous crossings. States point to these extreme measures taken by migrants hiding in lorries or ship holds as justification for migration controls, depicting interdictions as humanitarian missions. The discursive construction of rescue and migrant vulnerability justifies interdiction and policing practices, which in turn produce further moments of forced immobility for migrants.

As such, clandestine journeys have not only been securitized as a threat to communities, but have simultaneously been depoliticized and naturalized as humanitarian disasters. ${ }^{65}$ Both of these interpretations justify increased migration controls. For example, in early October 2013, over 400 migrants lost their lives only kilometers from Italian and Maltese shores. Italian, Maltese and European officials declared the incident a 'tragedy', 'accident', and 'succession of true slaughter of innocents', with little acknowledgement that state policies cause migrant deaths at sea. Indeed, in the humanitarian narrative, it is smugglers who are depicted as reckless killers and unscrupulous criminals, while migration controls become moral measures taken for the common good of saving lives in response to migration 'crises'. 66

The dual, contradictory nature of simultaneously rendering clandestine migration routes as a security threat and humanitarian problem was made plain in the Italian response to the migrant deaths in October 2013: the government provided a state funeral for the drowned and conferred on them posthumous Italian citizenship, while simultaneously branding the survivors as 'illegal', fining them $€ 5,000$, and incarcerating them in detention centers housing four times their normal capacity. ${ }^{67}$ Italian Prime Minister, Enrico Letta, subsequently announced the start of Mare Nostrum, a 'militaryhumanitarian mission' in the Mediterranean involving the use of amphibious ships, unmanned drones and long-range helicopters with infrared equipment. 68

Similarly, the language of rescue justifies the militarization of migration routes across Mexico. Since 2010, the word 'rescue' has become commonplace in official and newspaper reports of INM activities. Joel's story makes clear that rescues do happen. Nevertheless, human rights activists are skeptical of many rescue reports, arguing that such 'rescues' are usually interdictions and deportations (Field notes 1/11/11). As Sonja 
Wolf adroitly observes, the number of humanitarian visas to which rescued trafficking victims would be legally entitled has not kept pace with the number of so-called 'rescues'.69 The Mexican state deports 'rescued' migrants, like Joel, in spite of the humanitarian narrative that portrays them as victims of crime.

Although Mexican law restricts the military from playing a role in immigration enforcement, in practice and often under the guise of drug interdiction, the military collaborates with police and migration agents. The language of rescue provides an additional rationale for military intervention along migratory routes. Human rights activists are not the only critics of these so-called rescues. For example, the Guatemalan Foreign Ministry argued that the military did not, in fact, rescue 44 Guatemalan migrants from traffickers in Tamaulipas in February 2011, but instead simply intercepted and deported migrants who had been traveling voluntarily with their smugglers. ${ }^{70}$ Indeed, when U.S. border patrol apprehensions of Central American children increased dramatically in the summer of 2014, President Barack Obama announced his concern for "an actual humanitarian crisis on the border". ${ }^{71} \mathrm{~A}$ swift and dramatic crackdown on human smuggling operations based in Central America and increased raids on the migration routes through Mexico followed on the heels of this announcement. ${ }^{72}$ Humanitarian crisis justified the implementation of "aggressive deterrence" to dissuade migrants from making the journey. ${ }^{73}$

The humanitarian interpretation hinges on images of immobilized migrants in containers and boats taking physical risks too large to comprehend. Here, migrants become complete victims and their mode of travel becomes "entangled in the politics of migration". ${ }^{74}$ In the US context, Michael Andreas argues that the US Customs and Border Protection "excessively documents acts of failed migration... [and] has a particular interest in exposing these migrant bodies, unbelievably concealed in speaker boxes, glove compartments or seats, and presents them as vulnerable individuals, hiding in trunks or under hoods, encapsulated by dashboards or even sewn into seats." ${ }^{\prime 75}$ As our ethnographic data reveals, migrants who are 'rescued' are not saved from their physical or socioeconomic im/mobility, but rather face detention, deportation, and economic and social marginalization. 


\section{Conclusion}

The journey is often a solution to socio-economic and physical immobility suffered in countries of origin. Migrants express frustration with their inability to raise their families' standard of living and safety without international migration. However, to become upwardly socially mobile or geographically mobile, migrants must sometimes immobilize themselves, waiting patiently or confining themselves within safe houses, secret compartments, boats or other dangerous spaces. These moments within journeys represent both an expression of individual agency and a surrender of that agency. 'Agency' is an intangible concept of endless philosophical debate. Nevertheless, the corporeal scenes described in migrant narratives reveal the multiple layers of structural constraint and individual room for maneuver. Such narratives give a sense of how agency can be embodied in contradictory ways, leading migrants neither to emancipation nor enslavement to the borders imposed by states.

Similarly, a material culture of migration also renders the nested nature of journeys visible. Along the route, a growing number of places, social and material artifacts testify to immobility as inherent to movement. ${ }^{76}$ We find spaces for stopping, waiting and containment that constitute a landscape of im/mobility. Across Mexico, the last decade has witnessed a dramatic proliferation of detention facilities that contain migrants, smugglers' safe houses where people wait to make the next segment of their journey, and Catholic relief shelters where people stop, wait for remittances to continue their journey or receive other assistance. ${ }^{77}$ The material artifacts of moments of immobility accumulate along paths through the desert that separates/joins the United States and Mexico. ${ }^{78}$ On the edges of Europe, in the silent spaces of desert and sea, activists have also tried to create traces of migrant journeys through initiatives such as the Archive of Migrant Memories, Boats4People and the construction of the iconic 'Door to Europe' in Lampedusa, a monument dedicated to migrants who lose their lives in the Mediterranean Sea. In the Americas and the Mediterranean basin, these physical remains make visible and tangible the moments of immobility experienced during mobility. ${ }^{79}$

Indeed, the edges of both the United States and Europe are now sites of death as well as crossing. The International Organization for Migration estimates that over 22,400 people have died in the Mediterranean since 2000 while trying to enter the European 
Union. ${ }^{80}$ As many as 20,000 Central Americans may be kidnapped in passage across Mexico each year, ${ }^{81}$ and criminal gangs murder an unknown number of Central American migrants before they ever reach the dangerous desert passage at the U.S. border. Even those who are successful in their physical journey to Europe or the United States often do not escape the socio-economic immobility that may initially prompt their migration. Others do not escape the mobility of migration: they are (repeatedly) deported to countries of transit and origin, and (repeatedly) attempt to return..$^{82}$

Our analysis of the fragmented and nested reality of this life and death struggle contributes to a growing literature that troubles conventional dichotomies within migration studies. ${ }^{83}$ When the 'rite of passage' ${ }^{84}$ becomes a quasi-permanent life-style, the boundary between transit and settlement is elusive. The interplay between mobility and immobility blurs the distinction between voluntary and forced migration. The official rhetoric of rescue obscures the fragmented, matryoshka journeys of the state's own creation.

\section{NOTES}

${ }^{1}$ We refer to both labor immigrants and refugees as 'migrants'.

${ }^{2}$ E. Zilberg, Space of Detention: The Making of A Transnational Street Gang Crisis Between Los Angeles and San Salvador (Durham: Duke University Press 2011) p.3.

${ }^{3}$ E. Balibar, 'The Borders of Europe' in P. Cheah and B. Robbins (eds.), Cosmopolitics: Thinking and Feeling beyond the Nation (Minneapolis: University of Minnesota Press 1988) pp.216-232; A. Mountz, Seeking Asylum: Human Smuggling and Bureaucracy at the Border (Minneapolis: University of Minnesota Press 2010); W. Walters, 'Border/Control', European Journal of Social Theory 9/2 (2006) pp.187-203.

${ }^{4}$ M. Collyer, 'Stranded Migrants and the Fragmented Journey', Journal of Refugee Studies 23/3 (Aug 2010) pp.273-293; J. O'Connell Davidson, 'Troubling freedom: Migration, Debt and Modern Slavery', Migration Studies 1/2 (Feb. 2013) pp.176-195; F. Düvell, 'Transit Migration: A Blurred and Politicised Concept', Population, Space and Place 18/4 (July-Aug. 2012) pp.407481; S. Hess, 'De-Naturalising Transit Migration. Theory and Methods of an Ethnographic Regime Analysis', Population, Space and Place 18/4 (July-Aug. 2012) pp.428-440.

5 N. Brigden, Uncertain Odysseys: Migrant Journeys and Transnational Routes, PhD Dissertation, (Cornell University 2013); J. Carling, 'Migration Control and Migrant Fatalities at the Spanish-African Borders', International Migration Review 41/2 (June 2007) pp.316-343; Collyer (note 4); W. Vogt, 'Crossing Mexico: Structural Violence and the Commodification of Undocumented Central American Migrants', American Ethnologist 40/4 (2013) pp.764-780.

${ }^{6}$ We use William Sewell's broad definition of agency as having the capacity to exert 'some degree of control over the social relations in which one is enmeshed, which in turn implies the 
ability to transform those social relations to some degree'. W. H. Sewell Jr., 'A Theory of Structure: Duality, Agency, and Transformation', American Journal of Sociology 98/1 (1992) pp.1-29.

7 D. Conlon, 'Waiting: Feminist Perspectives on the Spacings/timings of Migrant (im)mobility', Gender, Place \& Culture, 18/3 (2011) p.355.

${ }^{8}$ E. Guild, C. Costello, M. Garlick, V. Morena Lax, and S. Carrera, 'Enhancing the Common European Asylum System and Alternatives to Dublin', Study for the European Parliament, LIBE Committee, July 2015.

${ }^{9}$ U.S. Customs and Border Protection, Department of Homeland Security, 'Southwest Border Unaccompanied Alien Children (FY 2014), available at <http://www.cbp.gov/newsroom/stats/southwest-border-unaccompanied-children-2014> accessed 19 Oct 2015.

${ }^{10}$ UNHCR, 'Children on the Run: Unaccompanied Children Leaving Central America and Mexico and the Need for International Protection,' (2014) available at <http://www.unhcrwashington.org/sites/default/files/UAC UNHCR Children\%20on\%20the\%2 ORun_Full\%20Report.pdf $>$ accessed 19 Oct 2015.

${ }^{11}$ U.S. Department of Homeland Security, 'Written testimony of USCIS Deputy Director Lori Scialabba, ICE Deputy Director Daniel Ragsdale and CBP Office of Border Patrol Chief Michael Fisher for a House Committee on the Judicial hearing titled "Asylum Abuse: Is it Overwhelming our Borders?" (2013) available at <http://www.dhs.gov/news/2013/12/12/written-testimonyuscis-ice-and-cbp-house-committee-judiciary-hearing-titled-">asylum accessed 19 Oct 2015.

${ }^{12}$ U.S. Customs and Border Protection, Department of Homeland Security, 'Southwest Border Unaccompanied Alien Children (FY 2015), available at $<$ http://www.cbp.gov/newsroom/stats/southwest-border-unaccompanied-children $>$ accessed 19 Oct 2015.

13 P. Andreas, 'Redrawing the Line: Borders and Security in the Twenty-first Century', International Security 28/2 (2003) pp.78-111; A. Mountz, Seeking Asylum: Human Smuggling and Bureaucracy at the Border (Minneapolis: University of Minnesota Press 2010); M. B. Salter, 'Passports, Mobility, and Security: How Smart Can the Border Be?', International Studies Perspectives 5/1 (Feb. 2004) pp.71-91.

${ }^{14}$ A. Mountz, 'Specters at the Port of Entry: Understanding State Mobilities through an Ontology of Exclusion', Mobilities 6/3 (2011) pp.317-34; cf. M. Sheller \& J. Urry, 'The New Mobilities Paradigm', Environment and Planning A 38/2 (2006) pp.207-26.

${ }^{15}$ P. Andreas, Border Games: Policing the U.S.-Mexico Divide (Ithaca: Cornell University Press 2000).

${ }^{16}$ Ibid; A. Chebel D'Appollonia, Frontiers of Fear: Immigration and Insecurity in the United States and Europe (Ithaca: Cornell University Press 2012).

${ }^{17}$ O. Ruiz, 'La Inmigración Indocumentada Como Metáfora de Riesgo en la Globalización', Estudios Sociológicos 23/2 (2005) p.613.

18 J. McC Heyman, 'Constructing a Virtual Wall: Race and Citizenship in U.S.-Mexico Border Policing', Journal of the Southwest 50/3 (Autumn 2008) p.310; J. P. Stumpf, 'Doing Time: Crimmigration Law and the Perils of Haste', UCLA Law Review 58/1705 (July 2011) pp.20112025.

${ }^{19}$ J. X. Inda, 'Subject to deportation: IRCA, 'criminal aliens, and the policing of immigration' Migration Studies 1/3 (Nov 2013) pp.292-310. 
${ }^{20}$ M. C. García, Seeking Refuge: Central American Migration to Mexico, the United States and Canada (Berkeley: University of California Press 2006).

21 A. Delano, 'From Shared Responsibility to a Migration Agreement? The Limits for Cooperation in the Mexico-United States Case 2000-2008', International Migration 50/1 (Feb. 2012) pp.e41-e50.

${ }^{22}$ A. Kimball, The Transit State: A Comparative Analysis of Mexican and Moroccan Immigration Policies, Center for Comparative Immigration Studies, UCSD Working Paper 150, 2007, p.78.

${ }^{23}$ R. R. Casillas, Una Vida Discreta, Fugaz y Anónima: Los Centroamericanos Transmigrantes en México (México DF: Comisión Nacional de los Derechos Humanos 2007).

${ }^{24}$ Ibid; C. Ogren, 'Migration and Human Rights on the Mexico-Guatemala Border', International Migration 45/4 (Oct. 2007) p.219.

${ }^{25}$ Ogren (note 24) p.211.

${ }^{26}$ Ibid, p. 218.

27 R. R. Casillas, 'Las Rutas de los Centroamericanos por Mexico, un Ejercicio de Caracterizacion, Actores Principales y Complejidades', Revista Migracion y Desarrollo 10 (2008) p.146.

${ }^{28}$ Ibid.

29 M. Meyer, 'A Dangerous Journey through Mexico: Human Rights Violations Against Migrants in Transit', Washington Office on Latin America (2010), available at $<$ http://www.seguridadcondemocracia.org/administrador de carpetas/biblioteca virtual/pdf/a d angerous journey through mexico wola.pdf $>$, accessed 11 April 2014, p.5; S. Wolf, 'Mexico's Conflicting Migration Policy Goals: National Security and Human Rights' Sustainable Security (11 April 2014), available at <http://sustainablesecurity.org/2014/04/11/mexicos-conflictingmigration-policy-goals/>, accessed 11 April 2014.

${ }^{30}$ A. Isaacson and M. Meyer, 'Mexico's Other Border: Security, Migration and the Humanitarian Crisis at the Line with Central America,' Washington Office on Latin America (2014), available at: <http://www.wola.org/files/mxgt/report/ >, accessed 19 Oct 2015.

31 'Estas son las principales acciones de la Programa Frontera Sur para proteger a los migrants,' AnimalPolitico (2014), available online at < http://www .animalpolitico.com/2014/08/estas-sonlas-principales-acciones-del-programa-frontera-sur-para-proteger-migrantes/>, accessed 19 Oct 2015.

${ }^{32}$ R. Dominguez Villegas and V. Rieteg, 'Migrants Deported from the United States and Mexico to the Northern Triangle: A Statistical and Socioeconomic Profile' Regional Migration Study Group, Migration Policy Institute (2015); M. Lohmuller, 'The Implications of Mexico's Rising Deportations,' InsightCrime (2015), available at <http://www.insightcrime.org/newsbriefs/implications-mexico-rising-deportations $>$, accessed 19 Oct 1015.

${ }^{33}$ Ibid; S. Nazario, 'The Refugees at Our Door,' Opinion Section, New York Times (2015), available at <http://www.nytimes.com/2015/10/11/opinion/sunday/the-refugees-at-ourdoor.html?_r=1>, accessed 19 Oct 2015.

${ }^{34}$ Wolf, 'Mexico's Conflicting Migration Policy Goals' (note 29).

${ }^{35}$ Ibid; INM, 'El Fenómeno Migratorio Debe Verse Desde el Ambito de la Seguridad Nacional: Vargas Fosado', Boletín NM 001/13 (2013), available at <http://www.inm.gob.mx/index.php/page/Boletin_0113> , accessed 12 April 2014. 
${ }^{36}$ S. Wolf, ¿¿Rescates de migrantes o intensificación del control migratorio?’ Animal Politico 14 (April 2014), available at <http://www.animalpolitico.com/blogueros-seguridad180/2014/04/14>, accessed 8 May 2014.

${ }^{37}$ Mainwaring has discussed this outward process, which she terms distalization, in more detail. C. Mainwaring, 'Resisting Distalization? Malta and Cyprus' Influence on EU Migration and Asylum Policies', Refugee Studies Quarterly 31/4 (2012) pp.38-66.

${ }^{38}$ S. Lavenex and R. Kunz, 'The Migration-Development Nexus in EU External Relations', Journal of European Integration 30/3 (July 2008) pp.439-457.

${ }^{39}$ M. Anderson, 'The Transformation of Border Controls: A European Precedent', in P. Andreas and T. Snyder (eds.), The Wall Around the West: State Borders and Immigration Controls in North America and Europe (Oxford: Rowman \& Littlefield 2000) pp.15-29.

${ }^{40}$ C. Boswell, 'The "External Dimension" of EU Immigration and Asylum Policy', International Affairs 79/3, (2003) pp.619-38; S. Lavenex, 'Shifting Up and Out: The Foreign Policy of European Immigration Control', West European Politics 29/2 (2006) pp.329-350; M. Samers, 'Emerging Geopolitics of Illegal Immigration in the European Union, An', European Journal of Migration and Law 6/1 (2004) pp.27-45.

${ }^{41}$ J. Cassarino, 'Informalising Readmission Agreements in the EU Neighbourhood', The International Spectator 42/2 (June 2007) pp.179-196.

${ }^{42}$ In practice, Morocco refused to readmit third-country nationals, claiming that there was no proof of transit in Morocco. Since 2003, however, third-country nationals were readmitted to Morocco if they had travelled by boat to Spain or the Canary Islands under the captaincy of a Moroccan national (J. Carling, 'Migration Control and Migrant Fatalities at the Spanish-African Borders', International Migration Review 41/2 (2007) pp.316-43.

${ }^{43}$ Return migration and Development Platform (RDP), 'Inventory of the agreements linked to readmission', (Florence, Italy: Robert Schuman Centre for Advanced studies, European Union Institute 2011), available at $<$ http://rsc.eui.eu/RDP/research/analyses/ra/>, accessed 3 May 2014.

${ }^{44}$ P. Cuttitta, 'Readmission in the Relations between Italy and North African Mediterranean Countries', in J. Cassarino (ed.), Unbalanced Reciprocities: Cooperation on readmission in the Euro-Mediterranean Area (Washington, D.C.: The Middle East Institute 2010) pp.30-52.

45 Associazione per gli Studi Giuridici sull'Immigrazione (ASGI), 'Gravi dubbi di legittimità dell'accordo tra Governo italiano e il CNT libico', Comunicato stampa, (24 June 2011), Translated into English by Niels Frenzen available at

$<$ http://migrantsatsea.org/2011/06/20/memorandum-of-understanding-between-italy-and-libyannct $/>$

${ }^{46}$ Frontex, Frontex Annual Report 2006 (Warsaw, Poland: Frontex 2007); N. Perkowski, 'A Normative Assessment of the Aims and Practices of the European Border Management Agency Frontex', Refugee Studies Centre Working Paper 81 (2012).

47 C. Mainwaring, 'Constructing a Crisis: the Role of Immigration Detention in Malta', Population, Space and Place 18/6 (Nov-Dec 2012) pp.697-700.

48 The European Court of Human Rights has ruled against the inadequate detention facilities in Malta and Greece, ordering both countries to pay damages to migrants who have been in held in inhumane and degrading conditions. European Court of Human Rights, Aden Ahmed v. Malta, application no. 55352/12 (23 July 2013); European Court of Human Rights, Suso Musa v. Malta, application no. 42337/12 (23 July 2013); European Court of Human Rights, Hirsi Jamaa and Others v. Italy, application no. 27765/09 (23 Feb. 2012); European Court of Human Rights, M.S.S. v. Greece and Belgium, application no. 30696/09 (21 Jan. 2011). 
${ }^{49}$ L. K. Cheliotis, 'Behind the Veil of Philoxenia: The Politics of Immigration Detention in Greece', European Journal of Criminology 10/6 (Nov. 2013) pp.725-745.

${ }^{50}$ Zilberg (note 2) p.4; cf. A. Innes, 'The Never Ending Journey? Exclusive Jurisdictions and Migrant Mobility in Europe', Journal of Contemporary European Studies, forthcoming.

${ }^{51}$ Collyer (note 4).

${ }^{52}$ M. Griffiths, 'Out of Time: The Temporal Uncertainties of Refused Asylum Seekers and Immigration Detainees', Journal of Ethnic and Migration Studies 40/12 (2014) pp.1991-2009.

${ }^{53}$ All names are pseudonyms.

${ }^{54}$ M. Breines, M. Collyer, D. Lutterbeck, C. Mainwaring, D. Mainwaring and P. Monzini, 'Study on Smuggling of Migrants: Characteristics, Responses and Cooperation with Third Countries Case, Study 2: Ethiopia - Libya - Malta/Italy’ European Commission (2015, forthcoming).

${ }^{55}$ N. Brigden, 'The Limits of Hometown Resources: Salvadoran Migration in Uncertain Times' Migration Studies (2014) pp.1-19.

56 Turkish visas allow travellers access to the Turkish Republic of Northern Cyprus, from where migrants cross without authorization into the southern part of the island, the Republic of Cyprus.

${ }^{57}$ United States Border Patrol. 'Southwest border sector deaths - FY 1998 through FY 2013', U.S. Border Patrol Fiscal Year Statistics (2013).

58 J. Ramos, Dying to Cross: The Worst Immigrant Tragedy in American History (New York: Harper Collins 2006).

${ }^{59}$ A. Smale, 'A Day After 71 Migrants Died, 81 Escaped the Back of a Truck in Austria, New York Times, 4 September 2015.

${ }^{60}$ N. De Genova, 'Migrant "Illegality" and Deportability in Everyday Life', Annual Review of Anthropology 31 (Oct. 2002) pp.419-447; N. Sigona, "I Have Too Much Baggage": The Impacts of Legal Status on the Social Worlds of Irregular Migrants', Social Anthropology 20/1 (Feb. 2012) pp.50-65.

${ }^{61}$ Malta maintains a mandatory immigration detention policy that confines all migrants arriving without authorization for up to 18 months, the maximum allowed in the European Union.

${ }^{62}$ Griffiths (note 52).

${ }^{63}$ J. P. Stumpf, 'Doing Time: Crimmigration Law and the Perils of Haste', UCLA Law Review 58 (2010) p.1705.

64 Brigden's interview with Walter fluctuated between Spanish and English. As with all interviews, his preference dictated the language we used at any moment. Most interviews were conducted in Spanish, but several interviews seamlessly mixed the two languages. All interview quotes are translations of handwritten notes, not recordings.

${ }^{65}$ M. Pugh, 'Drowning Not Waving: Boat People and Humanitarianism at Sea', Journal of Refugee Studies 17/1 (2004) pp.50-69.

${ }^{66}$ M. Albahari, 2006. 'Death and the Moral State: Making Borders and Sovereignty at the Southern Edges of Europe', CCIS Working Paper 135 (San Diego: Center for Comparative Immigration Studies 2006); Perkowski (note 46).

${ }^{67}$ Toby Vogel, 'Barroso to visit Lampedusa', European Voice (7 Oct. 2013).

${ }^{68}$ I. Traynor, L. Davies and C. Stephen, 'EU Urged to Tackle Boat People Crisis in

Mediterranean', The Guardian (13 Oct. 2013).

${ }^{69}$ Wolf, 'Mexico's Conflicting Migration Policy Goals' (note 29).

${ }^{70}$ E. Avila, ' 50 migrantes viajaban entre carga de naranjas' El Universal (10 Feb 2011). 
${ }^{71}$ Office of the Press Secretary, The White House, 'Remarks by the President on Border Security and Immigration Reform' (June 30, 2014), available at http://www.whitehouse.gov/the-pressoffice/2014/06/30/remarks-president-border-security-and-immigration-reform last accessed Nov 24, 2014.

${ }^{72}$ R. C. Archibald, 'On Southern Border, Mexico Faces Crisis of its Own' New York Times (July 19, 2014) available online at: http://www.nytimes.com/2014/07/20/world/americas/onsouthern-border-mexico-faces-crisis-of-its-own.html? $\mathrm{r}=0$ last accessed Nov 24, 2014; J.

Voorhees, 'What Immigration Crisis?' Slate (29 Aug 2014) available at:

http://www.slate.com/articles/news and politics/politics/2014/08/child migrant crisis the num ber of unaccompanied minors being arrest has.html last accessed Nov 24, 2014.

${ }^{73}$ Ibid.

${ }^{74}$ W. Walters, 'On the Road with Michel Foucault: Migration, Deportation, and Viapolitics' in M. Tazzioli, S. Fuggle, and Y. Lanci (eds.), Foucault and the History of Our Present (New York: Palgrave Macmillan forthcoming) p.6.

${ }^{75}$ M. Andreas, 'Copying Camouflage: In/visibility of Illegalized Immigration in Julio Cesar Morales' Series Undocumented Interventions', in C. Bischoff, F. Falk and S. Kafehsy (eds.) Images of Illegalized Immigration (New Brunswick; Transaction Publishers 2010) pp.59-60.

${ }^{76}$ Brigden (note 5) examines how migrants improvise upon this social and material infrastructure of the route. Such artifacts are not only useful to render im/mobility visible to researchers, but also become informational resources and points of vulnerability for migrants themselves.

${ }^{77}$ Casillas, Una Vida Discreta (note 23); Casillas, 'Las Rutas de los Centroamericanos por Mexico' (note 27)

78 J. De León, 'Better to Be Hot than Caught: Excavating the Conflicting Roles of Migrant Material Culture', American Anthropologist 114/3 (Aug. 2012) pp.477-495.

${ }^{79}$ V. Squire, 'Desert “trash”: Posthumanism, Border Struggles, and Humanitarian Politics', Political Geography 39/5 (March 2014) pp.11-21.

${ }^{80}$ International Organization for Migration (IOM), 'Fatal Journeys: Tracking Lives Lost during Migration' (Geneva, Switzerland: IOM, 2014) p.20.

${ }^{81}$ Comisión Nacional de los Derechos Humanos (CNDH), Informe Especial sobre los Casos de Secuestro en contra de Migrantes (Mexico City 2011).

${ }^{82}$ N. Hiemstra, 'Geopolitical Reverberations of US Migrant Detention and Deportation: The View from Ecuador', Geopolitics 17/2 (April 2012) pp.293-311.

${ }^{83}$ O'Connell Davidson (note 4)

${ }^{84}$ W. Kandal, and D. S. Massey, 'The Culture of Mexican Migration: A Theoretical and Empirical Analysis', Social Forces 80/3 (March 2002) pp.981-1004. 